Didaché: Journal of Christian Education

Vol. 2, No. 1 (2021): 73-86

e-ISSN: $2722-8584$

Published by: Sekolah Tinggi Teologi Simpson Ungaran

DOI: $10.46445 /$ djce.v2i1.384

\title{
Kriteria Guru Sekolah Minggu sebagai Gembala Anak Berdasarkan Yehezkiel 34:11-16
}

\author{
Jessica Dwikarja' ${ }^{1}$, Yanto P. Hermanto ${ }^{2}$, Tony Tedjo ${ }^{3}$ \\ 1,2,3 Sekolah Tinggi Teologi Kharisma, Bandung, Indonesia \\ Email: jedhe1101@gmail.com
}

\begin{abstract}
Sunday School ministry plays a pivotal role in introducing Jesus Christ as a Saviour to the children. As a children's pastor, Sunday School's teacher must have specific criteria to make the ministry grow even better. This research method is qualitative, followed by the descriptive analysis along with literature review toward the text in Ezekiel 34:11-16 "God, the True Shepherd (NKJV)." The study obtains three manners of God as a shepherd: God is gathering the scattered sheep, giving comforts to the sheep, and giving a proper rescue for each sheep. Leaning on those manners will lead the children's ministry in the church.
\end{abstract}

Keywords: children's pastor, Sunday-school teacher, criteria

\begin{abstract}
Abstrak
Pelayanan Sekolah Minggu dinilai penting untuk memperkenalkan Yesus Kristus sebagai Juruselamat kepada anak-anak. Guru Sekolah Minggu sebagai gembala anak harus memiliki kriteria tertentu agar pelayanan anak di dalam gereja dapat bertumbuh. Metode penelitian yang digunakan adalah kualitatif dengan analisis deskriptif dengan studi pustaka terhadap teks Yehezkiel 34:11-16 "Allah sebagai Gembala Israel yang Baik (TB)." Hasil penelitian menemukan tiga sikap Allah sebagai gembala yang menjadi kriteria bagi gembala anak yaitu Allah mengumpulkan domba yang terpencar, Allah memberikan kenyamanan bagi domba, dan Allah memberikan pertolongan yang tepat bagi setiap domba. Dengan dasar tersebut maka dapat mendukung pelayanan penggembalaan anak di dalam gereja.
\end{abstract}

Kata Kunci: gembala anak, guru Sekolah Minggu, kriteria

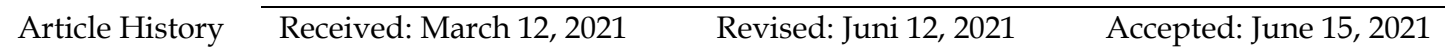

This is an open access article under the CC BY-SA license

\section{Pendahuluan}

Kegiatan Sekolah Minggu diawali oleh Robert Raikes yang menaruh belas kasihan pada anak-anak yang kurang mendapat pengajaran, baik itu pendidikan 
formal maupun firman Tuhan. Pada tahun 1780, Raikes memiliki ide untuk membuat sekolah pada hari Minggu, di mana anak-anak tidak mampu sedang libur dari bekerja (pada saat itu anak-anak berusia delapan tahun sudah bekerja selama enam hari). Raikes memberikan pelajaran menulis dan membaca secara gratis. Alasan Raikes melakukannya adalah ia seorang Kristen dan ia merasa wajib untuk menolong anak-anak itu. Raikes berharap dengan pendidikan dasar yang mereka terima dapat membawa mereka keluar dari hidup yang mengerikan (Gloucester City Council, n.d.). Selain pendidikan dasar, Raikes menyisipkan pengajaran mengenai 10 hukum Taurat agar anak-anak mendengar firman Allah. Kerinduan Raikes untuk memberikan edukasi dasar berkembang hingga saat ini menjadi Sekolah Minggu yang mengajarkan firman Tuhan bagi anakanak sedari kecil.

Masa ini, kegiatan Sekolah Minggu menjadi sebuah pelayanan gerejawi yang menjangkau anak-anak untuk mengenal Sang Juruselamat, Yesus Kristus. Mumo mengulas tujuan adanya kegiatan Sekolah Minggu menjadi empat hal dasar, yaitu pertama, untuk pengajaran Alkitab kepada anak-anak yang memperlengkapi mereka mengenai nilai dan pengalaman Kristen. Kedua, untuk membawa dan membimbing anak-anak mengenal siapa Kristus walaupun mungkin mereka terlahir dalam keluarga Kristen. Ketiga, untuk mengajarkan anak-anak mengaplikasikan nilai-nilai dalam Alkitab dalam kehidupan seharihari. Keempat, untuk mempersiapkan anak-anak menjadi anggota gereja atau jemaat yang berdampak melalui karunianya masing-masing (Mumo, 2016). Haaijer (2010) mengungkap bahwa anak-anak perlu diberi penjelasan dengan benar mengenai penginjilan, yaitu bahwa mereka adalah manusia berdosa secara natur, ada Yesus Kristus yang sanggup menyelamatkan, serta pada akhirnya pertobatan dan iman di dalam Yesus Kristus sebagai Juruselamat. Selaras dengan itu, Nale berpendapat bahwa Sekolah Minggu bukanlah sekedar sebuah program yang mendampingi jadwal rutin gereja setiap hari Minggu, namun lebih daripada itu Sekolah Minggu adalah prioritas gereja dalam hal memuridkan (Nale, 2007).

Melihat pentingnya kehadiran Sekolah Minggu mendorong gereja untuk memiliki guru-guru Sekolah Minggu yang mumpuni, yaitu yang memenuhi kriteria atau ukuran yang menjadi dasar penetapan seseorang layak untuk menjadi seorang guru Sekolah Minggu. Anak-anak berhak mendapatkan pengajaran dan pendidikan yang membawa mereka semakin mengenal kebenaran yaitu Yesus Kristus secara pribadi. Maka dari itu, Darmawan (2015) berpendapat 
bahwa panggilan menjadi guru Sekolah Minggu adalah suatu karunia Allah yang harus dijalankan dan dipertanggungjawabkan. Mengacu kepada perintah Yesus kepada Petrus untuk menggembalakan domba-domba-Nya (Yoh. 21:1519), begitu pula tanggung jawab guru Sekolah Minggu kepada anak-anak, yaitu menjadi gembala mereka. Allah sendiri menyatakan bagaimana cara menjadi gembala yang baik kepada Yehezkiel pada masa pembuangan. Di tengah kesedihan bangsa yang dibuang, Allah menunjukkan kasih dan janji-Nya kepada umat-Nya. Ia menyatakan ketidaksukaannya pada para gembala Israel (pemimpin umat) yang malah membawa bangsa Israel terperosok dalam berbagai dosa (Yeh. 34:1-8). Salah satu tanggung jawab dari gembala adalah menyediakan kebutuhan yang dibutuhkan oleh ternak mereka, dalam hal ini berkenaanjuga dengan fungsi gembala anak di Sekolah Minggu (Bangun, 2010).

Sayangnya, guru Sekolah Minggu beranggapan bahwa tugasnya hanya di hari Minggu, sementara kegiatan di hari Senin hingga Sabtu bukanlah tanggung jawabnya (Haaijer, 2010). Haaijer (2010) juga memberi ilustrasi guru Sekolah Minggu untuk selalu "membuka pintu" kapan pun anak-anak mengetok pintu, entah itu di hari Minggu ataupun di hari lain. Senada dengan hal ini, Windermere (n.d.) juga berpendapat bahwa guru Sekolah Minggu memiliki tanggung jawab untuk berperan sebagai pemimpin, konselor, pengajar, serta membangun hubungan secara pribadi dengan anak-anak. Proses ini tentu tidak dapat berjalan jika hanya mengandalkan pertemuan seminggu sekali. Seperti layaknya seorang gembala yang menjaga dombanya tiap-tiap waktu, begitu pula sosok guru Sekolah Minggu sebagai gembala anak seyogianya hadir dalam kehidupan anak-anak tiap waktu. Selain itu, guru juga adalah sosok teladan yang seharusnya dapat ditiru oleh anak-anak terutama dalam hal kerohanian dan moralitas selama menjalani keseharian (Junetri \& Widjaya, 2020). Statusnya sebagai pelayan dalam Sekolah Minggu menuntut mereka untuk menjadi teladan dalam hal nilai-nilai kristiani yang akan membentuk karakter, kecerdasan, serta spiritual anak-anak (Rantesalu, 2020).

Berdasarkan latar belakang tersebut maka rumusan masalah dalam tulisan ini adalah apa kriteria yang perlu dimiliki oleh gembala anak sesuai teladan sang Gembala Agung yang terdapat dalam perikop Yehezkiel 34:11-16? Tujuan penelitian ini adalah untuk mengurai peran gembala anak yang seharusnya dimiliki oleh guru-guru dalam pelayanan mereka di Sekolah Minggu. Pada akhirnya, gereja dapat menentukan, mengevaluasi, serta memperlengkapi guru Se- 
kolah Minggu dalam hal memperbaiki dan meningkatkan kualitas diri dan pelayanan sebagai gembala anak yang lebih baik lagi sesuai teladan Gembala Agung.

\section{Metode}

Penulis menggunakan metode penelitian kualitatif dengan metode analisis deskriptif melalui pendekatan studi pustaka seperti buku, jurnal, dan aplikasi Bibleworks, dan media online. Pengumpulan catatan tafsir khususnya perikop Yehezkiel 34:11-16 juga dilakukan untuk lebih memahami konteks perilaku Tuhan sebagai Gembala Israel yang baik serta aplikasi yang dapat diterapkan secara praktis dalam pelayanan Sekolah Minggu. Kesimpulan diambil melalui hasil analisis yang merumuskan tolak ukur atau kriteria guru Sekolah Minggu yang layak untuk menjadi gembala anak. Kriteria tersebut dapat menjadi pedoman bagi pemimpin gereja lokal demi membangun serta menetapkan gembala-gembala anak.

\section{Hasil dan Pembahasan}

Analogi mengenai gembala domba kerap muncul dalam kisah sejarah perjalanan bangsa Israel. Allah mengibaratkan diri-Nya sebagai Gembala sementara bangsa Israel atau umat percaya adalah domba-domba yang perlu dijaga dan dibimbing. Dalam Alkitab Terjemahan Baru Yehezkiel 33 sampai 48 memiliki judul sub-kitab yaitu Nubuatan Pengharapan Bagi Israel. Tafsiran Pulpit menuliskan bahwa bagian kitab ini adalah suatu visi akhir yaitu penantian akan pemulihan/restorasi Mesianik di masa yang akan datang (Spence-Jones, 1883). Termasuk pula pasal 34 yang dibahas dalam tulisan ini adalah suatu pengharapan akan seorang Gembala Agung yaitu Yesus Kristus yang akan menggembalakan setiap domba-Nya dengan cara yang benar.

Catatan tafsir Matthew Henry mengartikan bagian Yehezkiel 34:11-16 dengan walaupun gembala dunia (under-shepherds) ternyata berlaku sembrono, namun Allah sang Gembala Agung (chief Shepherd) adalah Penjaga Israel yang tidak terlelap dan tidak tertidur (Maz. 121:4) yang tidak akan gagal dalam menggembalakan (Bibleworks, n.d.). Konteks gembala Israel kala itu (Perjanjian Lama) merujuk pada para pemimpin bangsa yaitu raja atau pemimpin pemerintah lainnya. Bisa juga merujuk pada raja tirani seperti Raja Yoyakim dan Raja Zedekia yang melakukan hal jahat di mata Tuhan dan membawa kesesatan bagi bangsa. Mereka telah menjadi musuh dan berpura-pura saja sebagai gembala (Benson, 1857). Akibat perilaku gembala Israel yang sembrono, maka domba- 
domba menjadi tersebar (dalam penyerangan dan pembuangan) dan menderita. Tidak ada yang mempedulikan kehidupan mereka saat pembuangan. Melalui nubuat Yehezkiel, Allah menyatakan janji-Nya bahwa akan datang Seorang Gembala yang akan melawan para gembala Israel serta bertindak sebagai “Chief Shepherd" di mana semua domba akan dikumpulkan dan merasa aman dalam kawanan (Spence-Jones, 1883).

Dalam konteks modern, "gembala Israel" dapat diartikan sebagai "the pastoral office" atau "para pengurus gereja" yang memimpin dan membimbing jemaat (Spence-Jones, 1883), termasuk di dalamnya adalah para guru Sekolah Minggu. Junetri dan Widjaya (2020) menyatakan bahwa seorang guru Kristen perlu sadar bahwa ia tidak hanya mengemban gelar sebagai guru namun harus bisa mengarahkan muridnya pada tujuan yang mulia yaitu pengenalan akan Kristus. Fungsinya sebagai gembala harus sanggup menjadi contoh, teladan, model yang benar bagi dombanya, yang mencerminkan sikap hidup seorang Kristen (Berhitu, 2014). Agak sedikit berbeda dengan tanggung jawab penginjil, gembala perlu memiliki kemampuan sebagai pemelihara dan penjagaan sesuai dengan kebutuhan dan kondisi masing-masing dari tiap-tiap jemaat (Santoso, 2020). Menyadari pentingnya figur tersebut, gembala anak perlu bercermin pada nasihat dan teladan Yesus sendiri dalam penggembalaan karena Dialah Sang Gembala Agung.

\section{Tantangan Gereja mengenai Guru Sekolah Minggu}

Bagi gereja beraliran Pentakosta cenderung mengedepankan karunia roh dalam dirinya saat melakukan pelayanan gerejawi. Tidak salah, karena benar, sesuai perkataan Paulus dalam 1 Korintus 12:28 bahwa ada orang yang memiliki karunia sebagai pengajar. Dilengkapi dengan nasihat dari Yakobus 1:5-6 bahwa setiap orang perlu meminta hikmat dari Tuhan dan bertekun dalam iman serta pengajaran yang benar agar setiap apa yang disampaikan bukanlah sesuatu yang keliru. Tantangan yang dihadapi gereja adalah guru Sekolah Minggu yang melayani tidak memiliki dasar pengetahuan Alkitab yang cukup. Hanya bermodalkan "senang anak-anak" lalu kemudian diarahkan untuk mengajar Sekolah Minggu. Padahal Sekolah Minggu adalah suatu sarana utama untuk meletakkan dasar iman dalam Kristus, kebenaran firman, dan pengenalan karakter yang baik (Manubey, Degeng, \& Kuswandi, 2016). Sangat berisiko bila para pengajarnya ternyata tidak paham betul apa yang diajarkan dalam Alkitab, akibat fatalnya malah membawa anak-anak pada kesesatan. 
Tidak semua gereja memiliki pekerja full-timer yang fokus akan pelayanan anak. Sebagian pelayan termasuk guru Sekolah Minggu adalah simpatisan yang memiliki pekerjaan utama lainnya (bukan full-timer gereja). Fakta ini menjadi tantangan tersendiri bagi individu maupun tim pelayanan karena tidak bisa fokus waktunya untuk memikirkan berbagai kegiatan atau program Sekolah Minggu. Kreativitas dalam mengajar juga menjadi kurang, padahal ini adalah salah satu faktor penting untuk mendapatkan perhatian anak-anak saat kegiatan belajar atau ibadah (Tari \& Hutapea, 2020). Pengembangan ide-ide dan persiapan materi atau properti menjadi terbatas karena tidak menjadi fokus utama dalam kesehariannya.

Keterbatasan waktu yang dimiliki menjadi celah untuk malas meningkatkan kualitas diri. Pemikiran "segini juga sudah bagus" atau "cukup yang penting masih jalan" menjadi penghalang bagi kemauan untuk selalu belajar. Marbun (2009) melihat bahwa kondisi manusia cenderung menganggap bahwa belajar itu hanyalah pendidikan formal dari sekolah dasar hingga perguruan tinggi, padahal lebih dari itu pendidikan perlu dipandang sebagai cara hidup yang berlangsung terus menerus selama manusia hidup. Sependapat dengan Marbun, Darmawan (2015) menuliskan bahwa tiap pendidik seharusnya tidak berhenti belajar agar dapat terus mengikuti perkembangan zaman baik ilmu teologi dan Alkitab serta pola tingkah laku anak-anak. Pada akhirnya, pelayanan Sekolah Minggu menjadi lesu, kurang bersemangat, dan lama-lama jenuh.

Menyadari adanya tantangan tersebut, gereja perlu mengambil sikap untuk menghadapi dan menyelesaikannya. Kehadiran pemimpin gereja dalam hal ini gembala jemaat perlu membina para gembala anak dalam pelayanannya di Sekolah Minggu. Uraian mengenai kriteria gembala dapat menolong guru Sekolah Minggu kembali mengingat tugas dan tanggung jawabnya sebagai gembala dan berusaha menanggulangi tantangan yang dihadapinya. Dengan menyadari pentingya pelayanan ini, gembala jemaat dan gembala anak dapat bekerja sama dalam menjunjung tolak ukur yang harus dimilikinya yaitu meneladani sikap Sang Gembala Agung.

\section{Allah, Gembala Israel yang Baik}

Perikop Yehezkiel 34 secara keseluruhan membandingkan karakter dan perilaku gembala yang baik dan gembala yang jahat. Allah tidak berkenan pada perilaku gembala Israel yaitu raja yang membiarkan rakyatnya terpencar dan 
terbengkalai akibat serbuan bangsa lain (ayat 4-5). Raja malah memisahkan diri dalam istana tanpa peduli dengan kondisi rakyat yang menderita karena kehilangan rumah dan keluarga (Spence-Jones, 1883). Henry menafsirkan gembala yang berperilaku seperti itu tidak layak memiliki gelar gembala karena kondisi kawanan domba pada kenyataannya seperti tidak memiliki gembala (Henry, 1706). Mendapati bahwa wakil-Nya tidak menggembalakan dengan baik, Allah berjanji bahwa Ia akan melawan sendiri para gembala jahat. Tafsiran gembala jahat digambarkan sebagai gembala yang karena tingkah lakunya telah kehilangan kepercayaan Allah, mereka berpura-pura menggembalakan padahal apa yang dilakukannya malah memangsanya (ayat 10).

Dalam Yehezkiel 34:11-16 dituliskan mengenai cara Allah untuk memelihara domba-domba-Nya. Henry (1706) memaparkan tiga cara Allah menggembalakan domba-Nya, (1) Allah mengumpulkan domba yang terpencar, (2) Allah memberikan kenyamanan bagi domba, dan (3) Allah memberikan pertolongan yang tepat bagi setiap domba.

\section{Allah Mengumpulkan Domba yang Terpencar}

Masa pembuangan ke Babel membuat rakyat tercerai, tanpa induk, hilang tanpa arah. Namun Allah berjanji melalui Yehezkiel, suatu nubuatan tentang masa depan bahwa Ia sendiri akan mencari, mengumpulkan, dan membawa domba yang tercerai pada kawanan yang akan Ia jaga (ayat 11-12). Pengulangan beberapa kali frasa "Aku sendiri" dan "Aku akan..." menjadi suatu jaminan yang pasti bahwa Allah sendiri yang akan menyelamatkan domba yang hilang ke mana pun juga, bahkan di hari berkabut atau gelap. Yehezkiel 34:13 “Aku akan membawa mereka keluar dari tengah bangsa-bangsa dan mengumpulkan mereka dari negeri-negeri dan membawa mereka ke tanahnya;..." secara tersurat janji Allah untuk mengembalikan bangsa Israel dari negeri-negeri lain untuk kembali ke Israel yang kemudian nubuat ini terjadi saat kembalinya Zerubabel, Ezra, dan Nehemia kembali membangun bait Allah di Yerusalem (Henry, 1706).

Allah akan sanggup mendapatkan, menemukan, dan membawa dombaNya kembali. Seperti dalam Mazmur 139:7-10, Daud menyatakan bahwa Allah sang Gembala ada di mana pun, yang berarti tidak ada yang tersembunyi atau tidak terjangkau oleh kehadiran-Nya. Tangan-Nya akan senantiasa menuntun dan memegang domba yang hilang untuk kembali kepada kawanan. Komitmen ini juga senada dengan perumpamaan yang Yesus berikan dalam Lukas 15:3-7 bahwa seorang gembala akan meninggalkan sembilan puluh sembilan 
dombanya demi mencari satu domba yang hilang. Ayat 11 menekankan "Aku sendiri" yaitu gembala itu sendiri, bukan meminta orang lain atau pegawai lain untuk memperhatikan domba miliknya.

Allah Memberikan Kenyamanan bagi Domba

Penggembalaan yang Tuhan janjikan dalam Yehezkiel 34:14 “. . . tempat penggembalaan yang baik ... “ yaitu di mana domba dapat berbaring dengan tenang, dekat dengan alur sungai, dan rumput yang subur. Domba-domba dapat dengan tenang dan senang menikmati tempat tersebut tanpa kekurangan suatu apapun. Lagi dengan penekanan "Aku sendiri" akan menggembalakan dan membiarkan domba-domba berbaring atau beristirahat. Dalam ayat 15 Allah memberikan jaminan keamanan "Aku sendiri akan menggembalakan dombadomba-Ku dan Aku akan membiarkan mereka berbaring, demikianlah firman Tuhan ALLAH." Allah menjaga kawanan domba sehingga mereka dapat berbaring tanpa ketakutan akan adanya musuh.

Tiga hal yang Allah berikan dalam penggembalaannya menurut tafsiran Henry, (1) Padang rumput yang baik dan subur (good pasture and fat pasture) sebagai makanan bagi semua domba yang tentu akan memberikan kesegaran dan kesehatan bagi domba; (2) Tempat penggembalaan yang baik (good fold) atau bisa disebut juga suatu kandang yang baik dan nyaman sehingga domba dapat berbaring atau beristirahat dengan tenang; (3) Penjagaan oleh Allah sendiri yang menjamin domba dapat berbaring tanpa perlu takut adanya serangan (Henry, 1706).

\section{Allah Memberikan Pertolongan yang Tepat bagi Setiap Domba}

Yehezkiel 34:16 menuliskan beberapa tindakan aksi-reaksi antara domba dengan gembalanya: (1) Mencari yang hilang. Konteks ini menunjukkan domba yang mungkin sering kabur dari kawanan sehingga tersesat dan tidak tahu jalan pulang. Allah sebagai gembala akan mencarinya hingga ketemu; (2) Membawa pulang yang tersesat. Kata "tersesat" dalam bahasa Ibrani menggunakan kata נָרח (nadach) yang diartikan ke Alkitab versi KJV “was driven away" yang punya arti lebih tepat adalah terbuang atau terusir (Bibleworks, n.d.). Allah berjanji untuk membawa pulang setiap domba yang terbuat atau terusir dari kelompoknya. Seperti konteks masa pembuangan, bangsa Israel terbuang oleh rajanya sendiri, dan Allah hadir untuk membawa pulang mereka; (3) Membalut yang terluka. Kata "luka" menggunakan bahasa Ibrani שָׁבָ (shabar) yang berarti "break in pieces, rupture, crippled" yaitu kondisi patah menjadi beberapa bagian bahkan lumpuh. 
Allah sanggup membalut dan merawat luka terberat sekalipun; (4) Menguatkan yang sakit. Arti kata sakit pada konteks ini dapat diartikan lebih luas yaitu dalam keadaan lemah (weak), sakit secara fisik/mental (sick), penyakit yang berat (diseased), bahkan keadaan duka (grieved) (Bibleworks, n.d.). Allah berjanji untuk memberikan kekuatan dan ketabahan dalam menghadapi segala rasa sakit; (5) Menghancurkan yang gemuk dan kuat. Pada Alkitab Terjemahan Baru mencantumkan bahwa "yang gemuk dan yang kuat akan Kulindungi" yang dinilai kurang tepat jika dibandingkan dengan bahasa asli yaitu bahasa Ibrani yang digunakan. Kata “(domba) yang gemuk” menggunakan kata dasar שָָ (shaman) yang memiliki arti stout atau robust yang dapat diartikan dalam bahasa Indonesia yaitu gemuk atau kuat. Kata “(domba) yang kuat” menggunakan kata dasar חזָ (khazaq) yang memiliki arti strong atau kuat, namun pada konteks kalimat tersebut disebutkan dalam bad sense (buruk). Kata "Kulindungi" menggunakan kata dasar שֵַָׁר (shamad) yang diterjemahkan sebagai be destroyed, exterminated. Sehingga arti yang lebih tepat yaitu bahwa domba yang gemuk dan kuat dalam konteks buruk akan dihancurkan (Bibleworks, n.d.). Tafsiran Geneva memberi keterangan konteks domba yang kuat sebagai domba yang merasa dirinya lebih tinggi daripada domba lain dan merasa bahwa ia tidak perlu digembalakan oleh sang gembala ("Geneva Bible Study," 1560).

Ayat 16 ditutup dengan pernyataan: "Aku akan menggembalakan mereka sebagaimana seharusnya." Dalam versi NIV "I will shepherd the flock with justice." Tafsiran Geneva menilai bahwa konteks kata "justice" merujuk pada perlakuan yang berbeda bagi domba yang baik dan tidak baik, sebagaimana mereka pantas mendapatkan imbalan atas tingkah laku mereka ("Geneva Bible Study," 1560).

\section{Guru Sekolah Minggu sebagai Gembala Anak}

Dalam menjalani fungsi sebagai gembala anak, para guru Sekolah Minggu dapat meneladani sikap Allah saat menggembalakan domba-Nya. Pertama, melalui pelayanan Sekolah Minggu dapat membawa anak-anak untuk tergabung dalam komunitas yang benar, membangun, dan mengenal Yesus. Guru-guru mau memberikan waktunya untuk mengajak dan mengasuh anak-anak. Tidak hanya anak yang baik, namun anak yang nakal juga. Seperti teladan Yesus yang datang ke dunia untuk mencari orang berdosa yang memerlukan keselamatan (Luk. 5:32). Begitu pula dengan pelayanan Sekolah Minggu hadir untuk membawa anak-anak mengenal Yesus dan melakukan pembimbingan sejak dini agar mereka boleh berlaku baik dan berkenan. Agar dapat melakukan hal ini, guru 
Sekolah Minggu perlu memahami dan melakukan proses penggembalaan. Penggembalaan harus dilakukan terus menerus setiap hari, tidak bisa jika hanya sekedar pada jam ibadah sekali dalam seminggu (Bangun, 2010). Penggembalaan anak akan membawa kembali anak-anak yang mungkin tersesat karena pergaulan yang keliru, kebiasaan yang buruk, dan karakter yang tidak baik. Penggembalaan yang dilakukan dapat memperkenalkan anak-anak akan nilai-nilai yang benar serta aplikasinya sehingga hidup mereka lebih terarah dan terhindar dari hal-hal negatif yang menjurus kepada kenakalan dan membawa mereka kepada kesesatan (Latif, 2018). Gembala anak perlu memberikan dedikasinya dalam wujud waktu yang ia sediakan khusus untuk memperhatikan setiap anak yang digembalakannya setiap hari.

Selanjutnya, komunitas dan guru Sekolah Minggu harus menyediakan kenyamanan bagi anak-anak agar mereka kerasan berada dalam komunitas itu. Kenyamanan dapat berupa makanan rohani yang baik, tempat yang baik, serta penjagaan yang baik. Makanan rohani yang baik yaitu melalui bekal firman dan teladan yang benar dari para guru. Mimery (1996) menyatakan bahwa makanan rohani diperlukan setiap hari oleh semua jemaat. Dalam konteks tulisan ini yaitu memberikan bekal firman dalam porsi yang cukup dan kualitas yang tepat yaitu yang dapat diterima dengan baik dan mudah oleh anak-anak. Dalam hal teladan, gembala anak mewajibkan dirinya menjadi contoh yang baik dalam tutur kata dan tingkah laku ketika berada di depan anak-anak (Darmawan, 2015). Tempat yang baik berbicara pada persahabatan, fasilitas, dan kreativitas, sehingga anakanak nyaman berada dalam komunitas. Suatu komunitas penggembalaan akan menjadi sangat disenangi jika ada kenyamanan di dalamnya. Anak-anak bisa berekspresi dengan bebas, saling terbuka, tidak memiliki rahasia atau sesuatu yang sengaja ditutupi, bahkan saling mengenal satu anak dengan anak yang lainnya bahkan dengan guru-guru. Hubungan yang erat tentu saja akan memberikan kenyamanan dalam bersosialisasi dari sejak anak-anak hingga dewasa nanti. Tefbana, Hana, Supartini, \& Wijaya (2020) melalui penelitiannya menanggap pentingnya ruang Sekolah Minggu yang ramah anak, penggunaan alat peraga, multimedia untuk menarik perhatian anak-anak mengikuti ibadah. Guru yang kreatif dalam kegiatan ibadah Sekolah Minggu akan lebih mudah mendapat atensi anak-anak (Kristiono \& Perdana, 2019). Penjagaan yang baik akan selalu didasari oleh kasih yang terimplikasi dengan tindakan pemeliharaan yang nyata. Senduk menyoroti sebagai memelihara jiwa yang dimenangkan dan bertanggung jawab atas pertumbuhannya (Senduk, n.d.). 
Terakhir, melalui pengenalan akan setiap anak, guru-guru dapat memberikan pertolongan yang tepat bagi tiap-tiap anak. Pertolongan yang diberikan tentu saja demi pertumbuhan dan perkembangan anak-anak. Salah satu pertolongan yang dapat diberikan adalah berupa konseling. Guru Sekolah Minggu perlu terus memperlengkapi diri untuk belajar menangani anak-anak. Caranya dengan mengetahui kebutuhan mereka dan membimbing mereka secara pribadi untuk menyelesaikan masalah yang mereka hadapi (Djadi, 2007). Konseling anak termasuk dalam bentuk pendampingan pastoral yang merupakan panggilan bagi setiap orang merespon panggilan Allah tak terkecuali guru Sekolah Minggu (Engel, 2016). Melalui cara ini, guru Sekolah Minggu dapat memberikan pertolongan yang tepat bagi anak-anak sesuai kebutuhan masing-masing. Bentuk pertolongan lainnya yaitu dalam bentuk teguran. Seperti seorang gembala yang menggunakan lengkung pada tongkatnya untuk menarik domba yang kabur sehingga pasti leher domba tersebut terasa sakit. Begitupun gembala anak perlu berani memberikan teguran dengan cara dan waktu yang tepat bagi anak yang memerlukannya demi memberitahu kesalahan mereka. Teguran dan hukuman memang diperlukan demi anak-anak belajar taat dan hormat dalam kehidupannya. Seperti nasihat dalam Amsal 29:15 "Tongkat dan teguran mendatangkan hikmat, tetapi anak yang dibiarkan mempermalukan ibunya."

\section{Implikasi}

Implikasi bagi kriteria guru Sekolah Minggu yang berperan sebagai gembala anak adalah: Pertama, sebagai gembala anak memiliki kerinduan untuk senantiasa mengumpulkan dan membawa anak-anak dalam komunitas yang bertumbuh dalam hal nilai-nilai kerohanian. Kedua, memberikan dedikasi dalam wujud waktu dan komitmen untuk mempersiapkan bekal firman, alat peraga, serta perhatian dan pemeliharaan bagi anak-anak agar mereka merasa nyaman berada dalam komunitas tersebut. Ketiga, memberikan pertolongan dan pendampingan pastoral bagi setiap anak yang membutuhkan sesuai dengan kebutuhannya masing-masing.

Untuk mencapai kriteria tersebut, dapat dilakukan beberapa langkah praktis berikut: Pertama, harus mengenal betul dan bertanggung jawab penuh atas panggilannya sebagai guru Sekolah Minggu dengan mempersiapkan segala sesuatu yang berhubungan dengan ibadah dengan lebih baik. Misalnya dengan persiapan materi firman Tuhan, alat peraga, media, aktivitas, dan sebagainya. Tujuannya agar pesan firman dapat diterima dan dilakukan dengan baik oleh 
anak-anak. Kedua, mempererat hubungan pribadi dengan Tuhan agar pelayanan Sekolah Minggu bisa berdampak bagi kehidupan pribadi anak-anak melalui teladan kehidupan pribadi. Ketiga, memperdalam pengetahuan akan firman Tuhan agar makna firman yang disampaikan tidak keliru serta menyampaikan tema firman yang pas bagi anak-anak. Misalnya bisa dengan mengikuti pelatihan guru ataupun seminar teologi. Keempat, mendorong diri terus mencari hal-hal baru dalam pelayanan Sekolah Minggu agar tidak membosankan. Sarana internet dapat membuka wawasan para guru untuk melihat variasi ibadah, aktivitas, atau cerita unik yang dapat menggugah semangat anak. Kelima, mendekatkan diri untuk lebih mengenal anak-anak dengan menunjukkan rasa kasih dan peduli kepada mereka. Contohnya dengan mengikuti akun media sosial, memberi komen positif, mengunjungi atau melakukan video call pada tengah minggu. Dengan begitu, guru dapat membangun hubungan yang erat dengan anak-anak bahkan dengan oran tuanya, sehingga jika ada kesulitan lebih mudah dalam komunikasi. Keenam, bekerja sama dengan orang tua anak-anak dalam mengevaluasi pertumbuhan rohani anak-anak.

\section{Rekomendasi untuk Penelitian Lanjutan}

Hasil penelitian dapat menjadi acuan bagi penelitian selanjutnya yaitu untuk menentukan program bagi guru-guru untuk penerapan penggembalaan anak yang lebih baik dalam suatu komunitas Sekolah Minggu dalam gereja lokal. Faktor-faktor lain yang mendukung proses penggembalaan anak dapat digali dan dipaparkan lebih dalam lagi terutama sebagai pendukung untuk meningkatkan kualitas guru Sekolah Minggu sebagai gembala. Suatu program pelatihan bagi guru Sekolah Minggu juga dapat ditawarkan agar guru-guru memiliki peran yang berfungsi dengan lebih baik demi pengajaran dan komunitas yang lebih bertumbuh. Dalam penelitian ini penulis belum menghubungkan dan membahas penggembalaan anak di masa pandemi di mana pada waktu ini sedang terjadi. Dapat dibahas selanjutnya dalam penelitian ke depan bagaimana penggembalaan anak harus tetap berjalan walaupun kondisi pandemi, yang berakibat tidak bisa mengadakan ibadah tatap muka secara onsite di gereja.

\section{Kesimpulan}

Kehadiran gembala anak mengambil peran penting bagi anak-anak dalam ruang lingkup Sekolah Minggu di gereja. Gembala anak sendiri perlu memiliki 
kriteria atau tolak ukur yang setara dengan gembala jemaat, yaitu yang meneladani sikap Sang Gembala Agung. Dalam perikop Yehezkiel 34:11-16 ditemukan tiga sikap Allah sebagai gembala yang baik, yaitu Allah mengumpulkan domba yang terpencar, Allah memberikan kenyamanan bagi domba, dan Allah memberikan pertolongan yang tepat bagi setiap domba. Tiga hal ini menjadi kriteria bagi pelayanan gembala anak dalam Sekolah Minggu yaitu mampu mengumpulkan anak-anak dalam komunitas yang bertumbuh, memberikan kenyamanan (makanan rohani, tempat, dan penjagaan yang baik), serta kesediaan untuk memberikan pendampingan pastoral bagi setiap anak.

\section{Daftar Rujukan}

Bangun, Y. (2010). Integritas Pemimpin Pastoral. Yogyakarta: Andi.

Benson, J. (1857). Joseph Benson's Commentary on the Old and New Testaments.

Berhitu, R. J. (2014). Peran Gembala Jemaat Terhadap Pengembangan Pelayanan Holistik Di Gereja Kemah Injil Indonesia Jemaat Yegar Sahaduta Jayapura. Jurnal Jaffray, 12(2), 273-290. https:// doi.org/10.25278/jj71.v12i2.19

Bibleworks. (n.d.).

Darmawan, I. P. A. (2015). Dasar-dasar Mengajar Sekolah Minggu. Ungaran: Sekolah Tinggi Teologi Simpson.

Djadi, J. (2007). Metode Pastoral bagi Anak Sekolah Minggu. Jurnal Jaffray, 5(1), 1-6.

Engel, J. D. (2016). Pastoral dan Kebutuhan Dasar Konseling. Jakarta: BPK Gunung Mulia.

Geneva Bible Study. (1560).

Gloucester City Council. (n.d.). Robert Raikes.

Haaijer, J. (2010). The Evangelism of Children. Langenbruck: European Child Evangelism Fellowship.

Henry, M. (1706). Matthew Henry commentary on the whole Bible (complete). Junetri, G., \& Widjaya, Y. A. (2020). Kepemimpinan Guru Kristen: Sebuah Tinjauan Etika Kristen. BIA' Jurnal Teologi Dan Pendidikan Kristen Kontekstual, 3(2), 198-213. https:/ / doi.org/10.34307/b.v3i2.149

Kristiono, T., \& Perdana, D. P. (2019). Hambatan Guru dan Pelayanan Sekolah Minggu di Gereja Kristen Jawa Jebres Surakarta. Jurnal Teologi Gracia Deo.

Latif, H. F. (2018). Pengaruh Pengajaran dan Persekutuan Terhadap Tingkat Pertumbuhan Rohani Anak dan Remaja. EPIGRAPHE: Jurnal Teologi Dan Pelayanan Kristiani, $1(2)$, 119-138. 
https:// doi.org/10.33991/epigraphe.v1i2.18

Manubey, J., Degeng, I. N. S., \& Kuswandi, D. (2016). Pengembangan Bahan Ajar Untuk Di Sekolah Minggu. Pendidikan: Teori, Penelitian, Dan Pengembangan, 1(3), 526-535.

Marbun, P. (2009). Making Life Better. Yogyakarta: Andi.

Mimery, N. (1996). Rahasia Tentang Penggembalaan Jemaat. Jakarta: Mimery Press. Mumo, P. M. (2016). The Role of Sunday Schools in Christian Socialisation of Children in Africa: A Case Study of Africa Inland Church in Kenya. Ilorin Journal of Religious Studies, 6(1), 44-58.

Nale, B. E. (2007). Sunday School as a Viable Tool for Church Growth in the 21st Century. Liberty Baptist Theological Seminary.

Rantesalu, S. B. (2020). Pemberlakuan Kurikulum Berbasis Nilai dan Karakter dalam Pembelajaran Pendidikan Agama Kristen Terhadap Kecerdasan Spiritual Siswa SMA Negeri Di Tana Toraja. BIA': Jurnal Teologi Dan Pendidikan Kristen Kontekstual, 3(2), 214-229. https://doi.org/10.34307/b.v3i2.152

Santoso, Y. (2020). Efektivitas Peran Gembala Jemaat dalam Pertumbuhan Gereja. KHARISMATA: Jurnal Teologi Pantekosta, 2(2), 88-100. https:// doi.org/10.47167/kharis.v2i2.35

Senduk, H. (n.d.). Pedoman Pelayanan Pendeta Jilid II. Jakarta.

Spence-Jones, H. D. . (1883). Pulpit Commentary.

Tari, E., \& Hutapea, R. H. (2020). Peran Guru dalam Pengembangan Peserta Didik di Era Digital. Kharisma: Jurnal Ilmiah Teologi, 1(1), 1-13.

Tefbana, I. I., Hana, S. R., Supartini, T., \& Wijaya, H. (2020). Kompetensi Guru Sekolah Minggu Terhadap Keefektifan Mengajar Anak: Suatu Studi Kuantitatif Di Jemaat GPdI El-Shaddai Makassar. Didache: Journal of Christian Education, 1(2), 205. https://doi.org/10.46445/djce.v1i2.360

Windermere, A. (n.d.). The Role of a Children's Pastor. 